\title{
COVID-19 Complicated with Arterial Thrombosis Resulting Acute Limb Ischemia: A Case Report from Bangladesh
}

\author{
Md. Reaz Uddin Chowdhury ${ }^{1}$, Kazi Shanzida Akter ${ }^{2}$, Sahedul Islam Bhuiyan ${ }^{3}$, Bimal Chandra \\ Das $^{4}$, Mohammad Moksedul Moula ${ }^{5}$, Fazla Alahi Khan ${ }^{6}$, Sohel Rahman ${ }^{7}$, Arifa Akram ${ }^{8}$
}

${ }^{1}$ Consultant, Department of Medicine, Abdul Malek Ukil Medical College, Noakhali, Bangladesh; ${ }^{2}$ Resident Medical Officer, Dedicated COVID-19 Hospital-Trauma Center, Feni, Bangladesh; ${ }^{3}$ Professor, Department of Respiratory Medicine, Brahmanbaria Medical College, Brahmanbaria, Bangladesh; ${ }^{4}$ Associate Professor, Departments of Paediatrics, Abdul Malek Ukil Medical College, Noakhali, Bangladesh; ${ }^{5}$ Resident Medical Officer, Medinova Specialized Hospital, Feni, Bangladesh; ${ }^{6}$ Assistant Professor, Nephrology, Abdul Malek Ukil Medical College, Noakhali, Bangladesh; ${ }^{7}$ Medical Officer, Department of Epidemiology, Institute of Epidemiology Disease Control \& Research, Bangladesh; ${ }^{8}$ Assistant Professor, Department of Virology, National Institute of Laboratory Medicine and Referral Center, Dhaka, Bangladesh

[Received: 17 August 2020; Accepted: 28 September 2020]

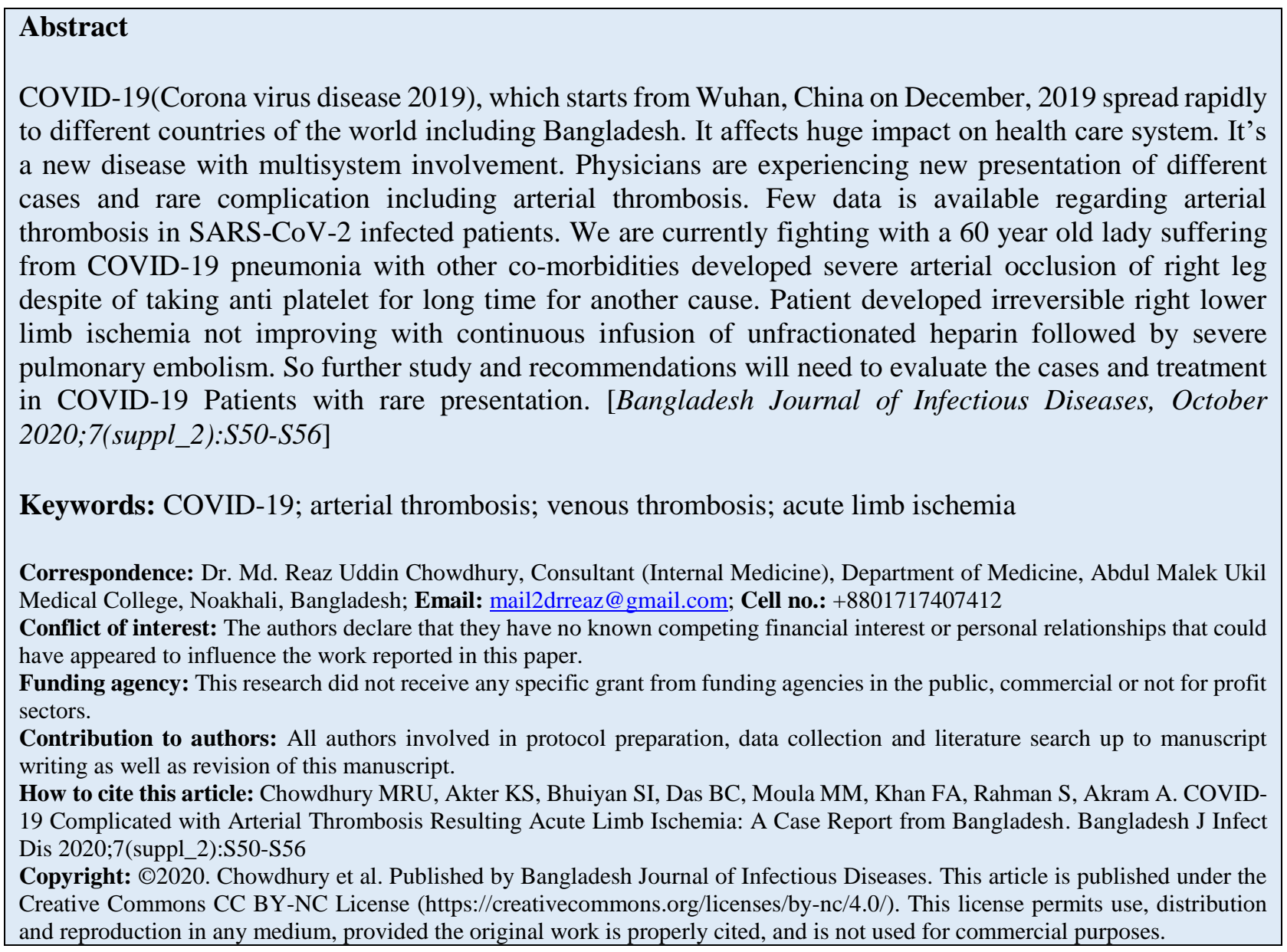




\section{Introduction}

Novel coronavirus (2019-nCoV) was first reported in Wuhan, China. Since then SARS-CoV-2 has generated 16207130 confirmed cases of COVID-19 worldwide with a confirmed death of 648513 cases till July 26, 2029 ${ }^{1}$. The total numbers of confirmed COVID-19 cases in Bangladesh are 221178 with total confirmed death of 2874 till July 26, $2020^{2}$.

Unusual presentations of COVID-19 were unknown when it first emerged in Wuhan, China. Initially the virus presented with high fever, cough, tiredness, sore throat and aches and pains. Subsequently cases of diarrhoea, conjunctivitis, headache and loss of smell were often accompanying the illness ${ }^{3}$.

Although respiratory failure is the main cause of death of moderate to severe COVID-19 disease, several cardiovascular complications and numerous cases of thromboembolic disease have been reported ${ }^{4,5}$. Coagulopathy is an emerging and often lethal complications ${ }^{6}$. However, venous thromboembolism (VTE) is common in COVID-19 patients ${ }^{7}$. Despite the pathophysiology of an underlying prothrombotic state, data and regarding the risk of acute arterial thrombotic events are still rare and only a few reports of arterial thromboembolism ${ }^{8}$. COVID-19 with multiple comorbidities associated with severe disease and increase mortality ${ }^{9}$. The most common comorbidities found were obesity, hypertension and diabetes mellitus ${ }^{10}$. Older adults and people of any age, who have underlying medical conditions such as hypertension and diabetes, have shown worse prognosis $^{11}$. The aim was to report this case to describe the clinical characteristics of the patient during presentation, treatment response of the case, choice of anti-thrombotic and to familiarize our fellow colleague to share the experience of an unusual presentation of a COVID-19 Pneumonia with multiple co-morbidities.

\section{Case Presentation}

A 60 years old obese (BMI -39) woman presented to the hospital on July 11, 2020 with the complaints of fever for 11 days which was intermittent, high grade, highest recorded temperature was $104^{0} \mathrm{~F}$, she have to take antipyretic paracetamol for relieving her fever, cough with expectoration of scanty sputum but not any history of haemoptysis, shortness of breath and generalized weakness for same duration. She admitted with a positive report of Corona by RT PCR from nasopharyngeal swab 5 days before. She had no history of headache, diarrhea, arthralgia or any other unusual symptoms. She denied any contact with positive COVID-19 patients. Exploration of past medical history included hypertension for 5 years, chronic persistent bronchial asthma controlled on medication for 5 years, hypothyroidism for 4 years, and ischemic heart disease for 2 years taking anti ischemic drugs and dyslipidaemia taking lipid lowering drug, atorvastatin $20 \mathrm{mg}$ daily for 3 years. She reported no previous history of cerebrovascular or peripheral vascular disease. On admission physical examinations revealed a temperature of $104^{0} \mathrm{~F}$, Blood pressure of $150 / 90 \mathrm{~mm}$ of $\mathrm{Hg}$, pulse of $102 / \mathrm{min}$ with normal rhythm and volume, respiratory rate was 22 breath per minute and oxygen saturation of $88 \%$ on room air immediately put on supplemental oxygen though she was not in acute distress, there is bilateral pitting oedema of the both legs. Lung auscultation showed few scattered course crackles over the both lung field with polyphonic rhonchi. There was no evidence of VTE on examinations. Initial Chest $\mathrm{X}$ ray showed bilateral interstitial pneumonitis (Figure I).

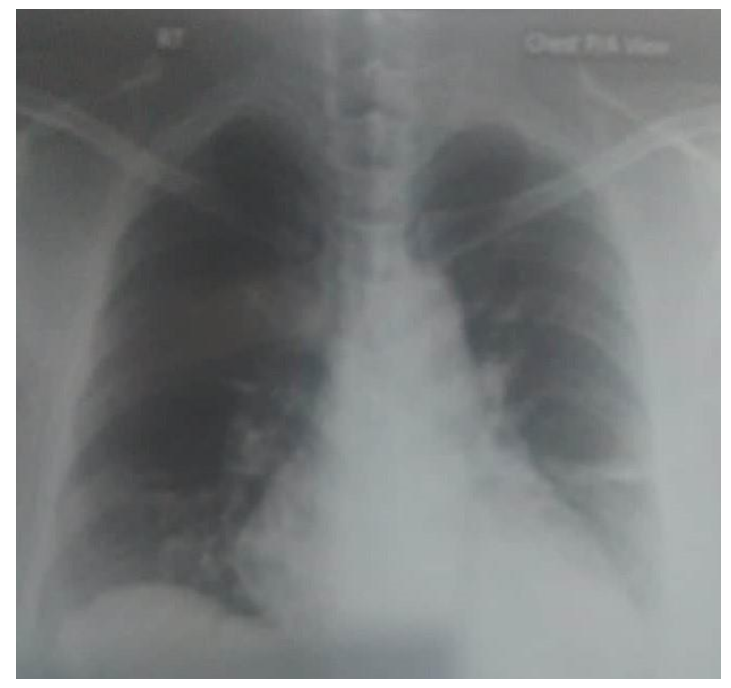

Figure I: Chest $X$ ray posterior-anterior view on admission showing Bilateral Interstitial pneumonitis with peripheral distribution

High resolution computed tomography of chest(HRCT of chest) (Figure II and III) was performed which revealed multifocal ground glass density areas intermixed with multifocal sub segmental consolidations, irregular attenuated areas and fibrotic bands are seen at multiple segments of both lungs predominantly distributed at peripheral, peribronchoalveolar and sub pleural regions. The ground glass opacity and consolidations involved approximately $30 \%$ of lung volume. 


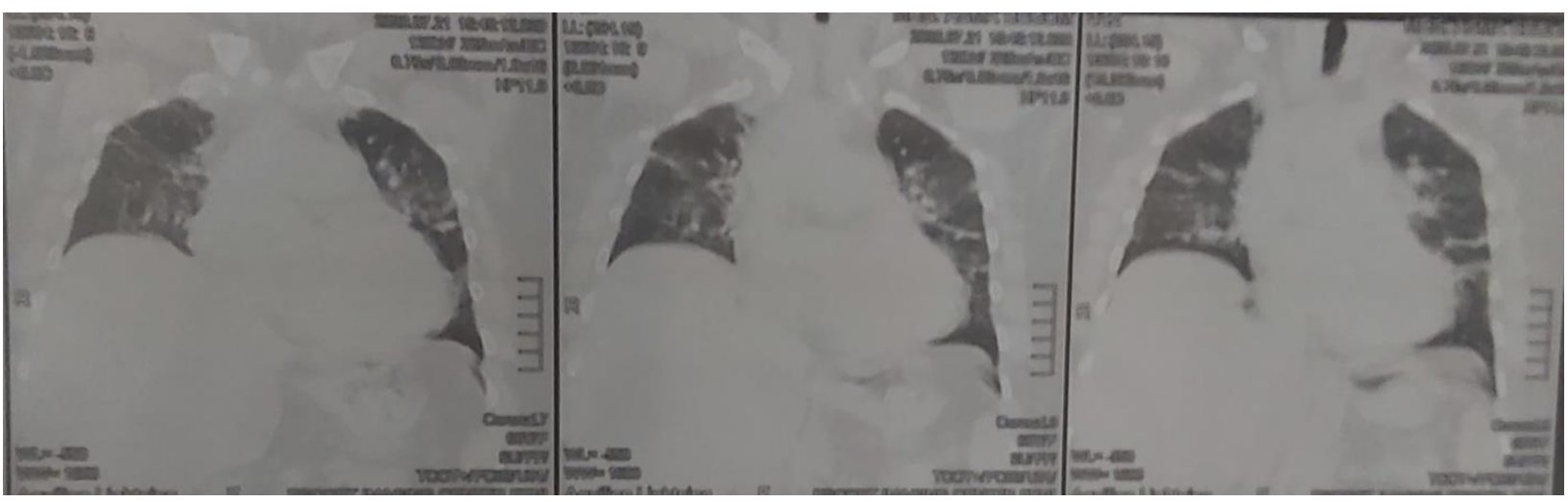

Figure 2 (A and B): HRCT of chest coronal view showing crazy paving with ground glass opacity and consolidations in the both lungs involved approximately $30 \%$ of lung volume

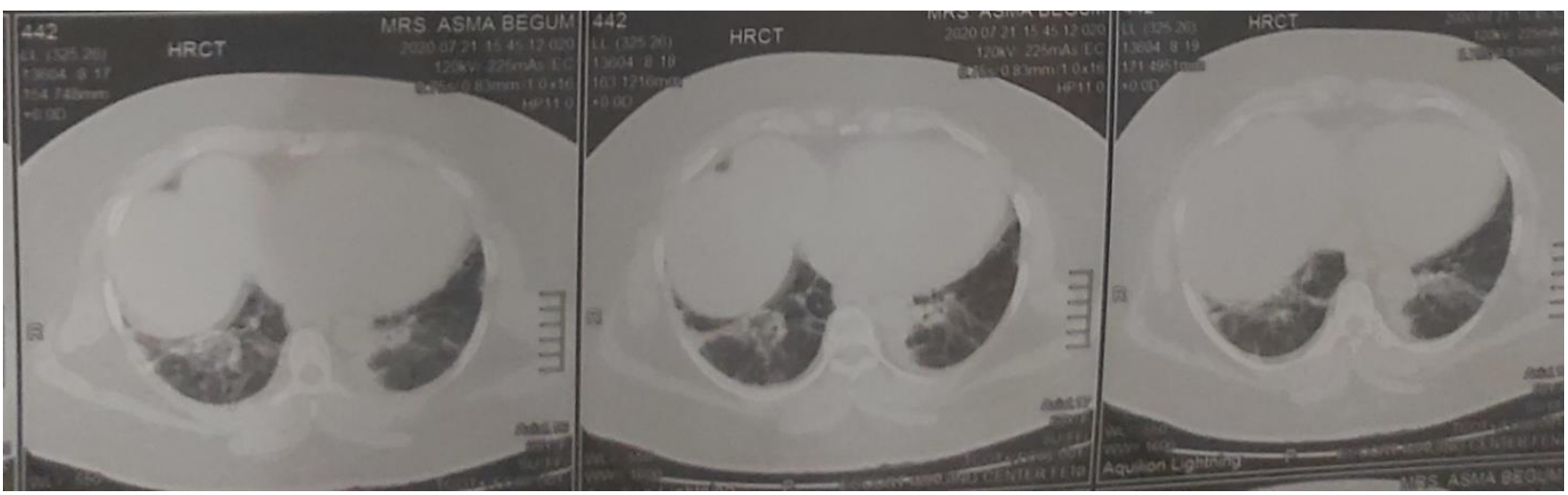

Figure 3: (A, B and C) HRCT of chest coronal view showing multifocal ground glass density areas intermixed with multifocal sub segmental consolidations, irregular attenuated areas and fibrotic bands are seen at multiple segments of both lungs predominantly distributed at peripheral, peribronchoalveolar and sub-pleural regions.

Other significant laboratory findings included haemoglobin was $7.6 \mathrm{gm} / \mathrm{dl}$, erythrocyte sedimentation rate (ESR) was $74 \mathrm{~mm}$ in $1^{\text {st }}$ hour, and Total white blood cell count (WBC) was $14,000 / \mathrm{cmm}$ with $74 \%$ neutrophils and $13.0 \%$ lymphocyte in differential count. Packed cell volume(PCV) was $24.2 \%$, serum creatinine was $2.4 \mathrm{mg} / \mathrm{dl}$ with estimated GFR was 56 $\mathrm{ml} / \mathrm{min} / 1.73 \mathrm{~m}^{2}$, c reactive protein(CRP) was 64 $\mathrm{mg} / \mathrm{L}$, serum ferritin was $711 \mathrm{ng} / \mathrm{ml}$, D-dimer was $0.81 \mathrm{mg} / 1$,Alanine aminotransferase was $23 \mathrm{U} / \mathrm{L}$, serum urea $23 \mathrm{mg} / \mathrm{dl}$, blood urea nitrogen was 22.7 $\mathrm{mg} / \mathrm{dl}$, serum calcium was $6.1 \mathrm{mg} / \mathrm{dl}$, phosphate was $5.9 \mathrm{mg} / \mathrm{dl}$, peripheral blood film showed microcytic hypochromic anemia with neutrophilic leukocytosis. She was started on enoxaparin $60 \mathrm{mg}$ subcutaneous 12 hourly, oral favipiravir $1600 \mathrm{mg}$ loading dose followed by maintenance dose $600 \mathrm{mg}$ 12 hourly for 10 days, intravenous meropenem $500 \mathrm{mg} 3$ times daily and oral clarithromycin $500 \mathrm{mg}$ twice daily along with her regular antihypertensive medications amlodipine $5 \mathrm{mg}$,olmesartan 20mg, clopidogrel $75 \mathrm{mg}$, nitroglycerine $2.6 \mathrm{mg}$ twice daily, trimetazidine $35 \mathrm{mg}$ twice daily, bisoprolol $5 \mathrm{mg}$ daily, atorvastatin $20 \mathrm{mg}$ daily and regular antiasthma medication metered dose inhaler formeterol/ Beclomethasone combination along with salbutamol and montelukast $10 \mathrm{mg}$ daily along with levothyroxine $100 \mathrm{micgm}$ daily. She was admitted to an isolation unit and started on supplymental oxygen via simple face mask at $5-6 \mathrm{~L} / \mathrm{min}$. She was nor screened for VTE at admission. Her symptoms and vital signs remained stable in the first 1-4 days following admission although she continued to require supplemental oxygen. On hospital day 6 , she began complaining of right lower extremity pain which increasing with time. After that thorough physical examination was done and found absent dorsalis pedis, posterior tibial and feeble anterior tibial artery pulse in her right foot and leg which was remain cooler than her contralateral foot. The intensity of pain increasing with time. She was found to have diminished sensation also in her right foot, anterior and posterior aspect of the right leg, consistent with Rutherford Class III ALI. After that emergency duplex study was performed (Figure IV) and found arterial spectral flow on the right femoral artery PsV: $48 \mathrm{~cm} / \mathrm{sec}$, right popliteal artery was PsV: $19 \mathrm{~cm} / \mathrm{sec}$, no recordable blood flow was seen right anterior tibial, posterior tibial and dorsalis pedis arteries, in the left side which were normal. 

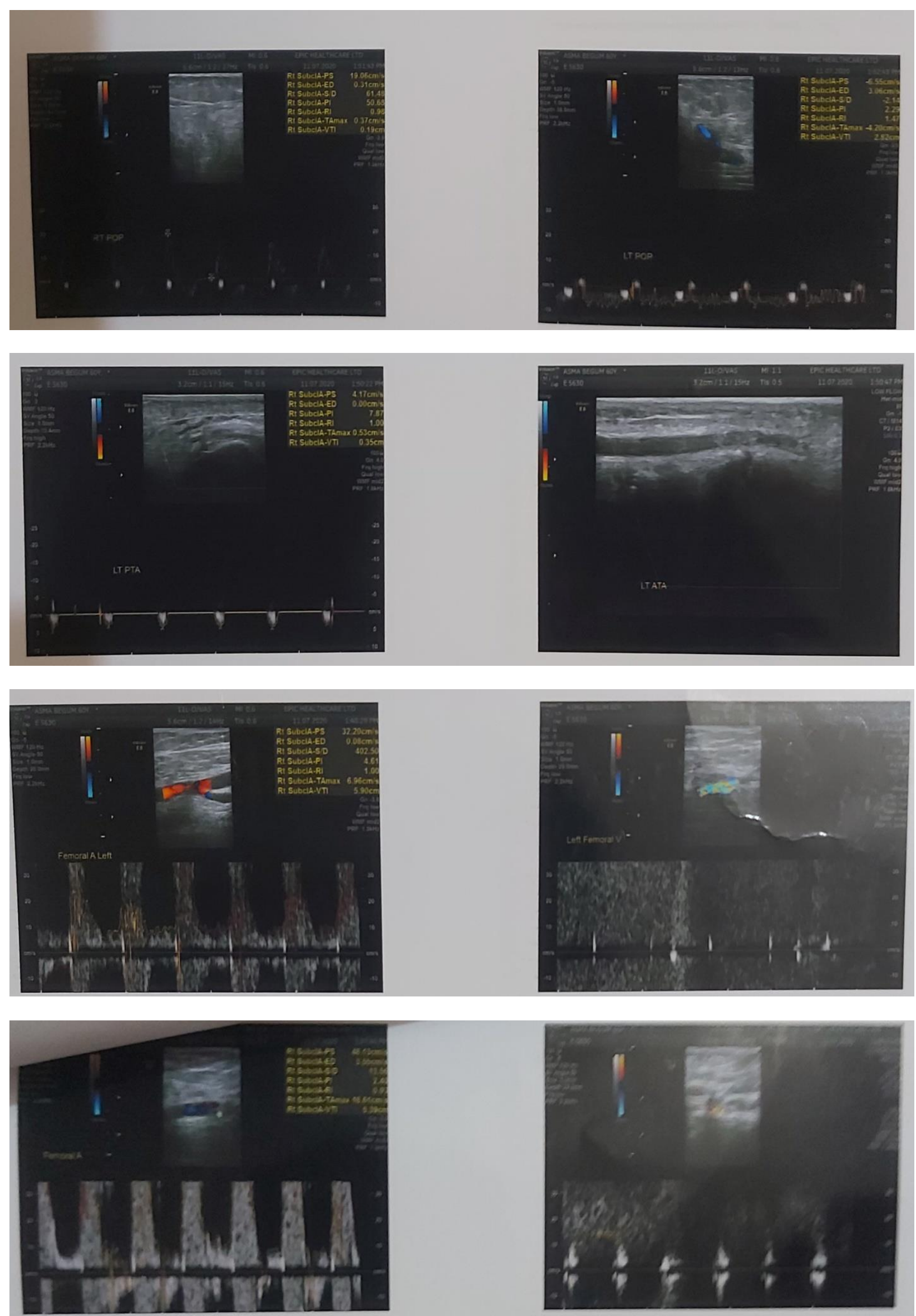

Figure 4(A,B and C): Duplex ultrasound of the Lower limb vessels Showing no recordable blood flow in the Right anterior tibial, posterior tibial and Dorsalis pedis arteries, Contralateral arteries were normal. The spectral flow pattern of the venous system was normal in both side 
The spectral flow pattern of the venous system was normal. Normal respiratory variance was seen. Calf compression test was normal on both sides. CT angiography of lower extremities was planned but cannot possible due to rapid deterioration of the patient. Echocardiography showed concentric left ventricular hypertrophy with anterior regional wall motion abnormality with ejection fraction $64 \%$ and normal right ventricular systolic function. Antinuclear antibody (ANA) and anti-phospholipid antibody was found negative. After that she was started with unfractionated heparin 5000 IU loading dose followed by continuous infusion of $1000 \mathrm{IU} / \mathrm{hr}$ but her condition worsened with increasing breathlessness, she became increasingly tachypneic with respiratory rate more than 28 with fluctuation saturation $80-90 \%$ put on non-rebreather mask with supplemental oxygen $12-15 \mathrm{~L} / \mathrm{min}$. Two units of packed cells and $200 \mathrm{ml}$ of convalescent plasma given during this period. All other investigation reviewed and found markedly elevated D-dimer with other parameters. She was seen by a surgeon but postponed any procedure due to her worsening condition. After that she was also started with antiviral, Remdesivir 100mg daily along with other drugs. Activated plasma thromboplastin time (APTT) was found within normal limit in the follow up. But her condition not improved at all rather increasing pain in the right leg with gradual blackening of the toes and developed blister over the anterior surface of the foot (Figure V).

Increasing breathlessness and desaturation requiring more oxygen, put on high flow nasal canola to provide $50 \mathrm{~L} / \mathrm{min}$ oxygen. Following two days her saturation was maintained above $92 \%$ but pain and pulsation in the right legs not improved. She was also started intravenous methylprednisolone $250 \mathrm{mg}$ that time daily. But on day 16 July 25, 2020 in the hospital her conditioned become worsened with fall of oxygen saturation and put on ventilation. Planned for computed tomography pulmonary angiography (CTPA) and CT angiogram of the bilateral lower extremities but not possible due to patient condition. A portable X-ray chest was taken (Figure VI) which showing bilateral extensive involvement of both lungs. On July 26, 2020 at $10 \mathrm{pm}$ she developed hypotension followed by cardiac arrest leading to initiation of nor-epinephrine and cardiopulmonary resuscitation but cannot recovered. Informed consent was obtained from the patient for publication of this case report.

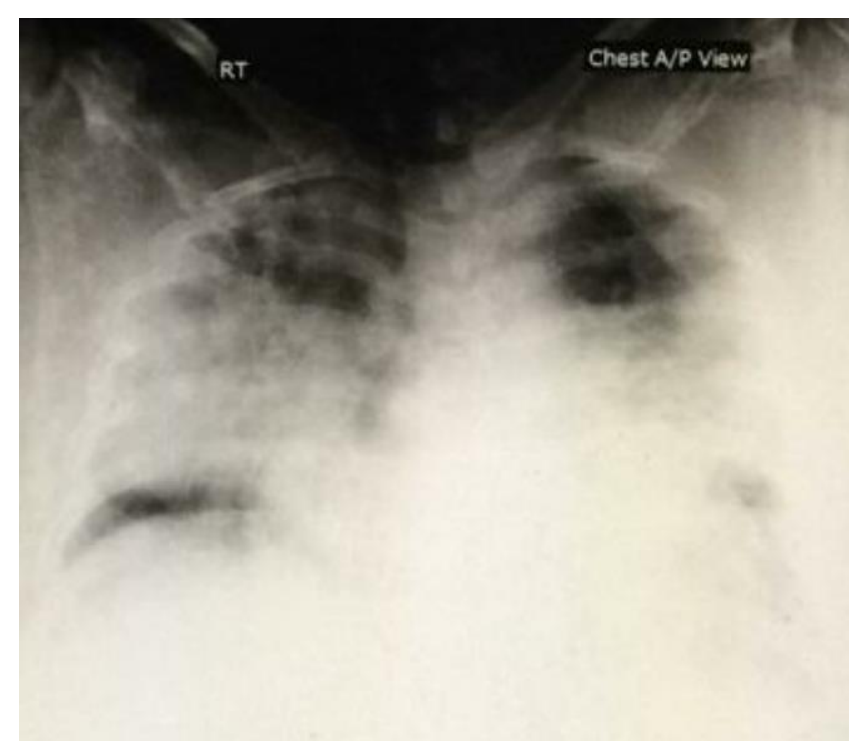

Figure 6: Chest $X$ ray Anterior-posterior view Showing Extensive Bilateral Involvement of both Lungs (July 25, 2020)

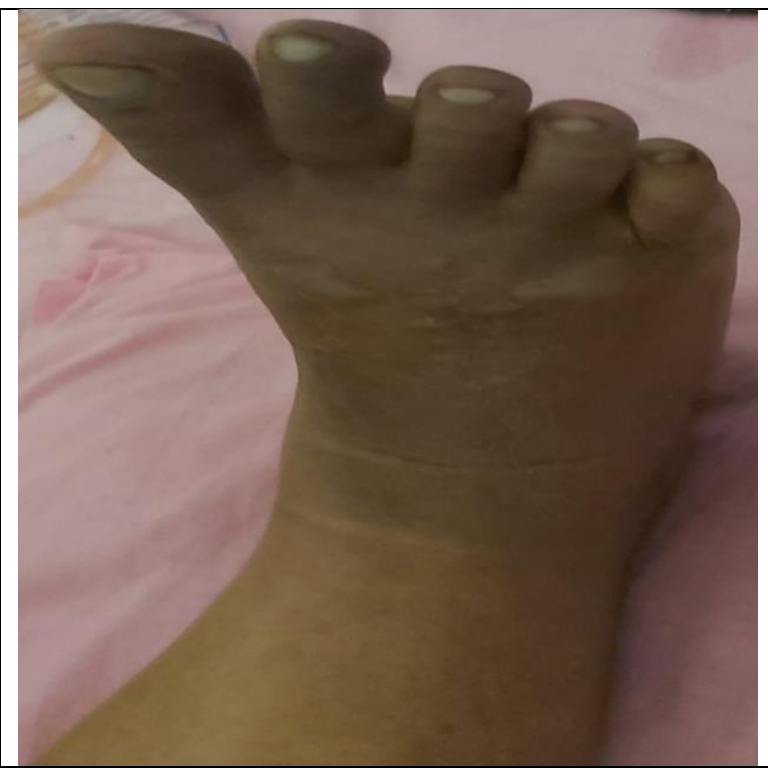

Figure 5(A and B): Showing blackening of big toe including other toes(A) and blister formation on the dorsum of the foot with blackening of $\operatorname{skin}(B)$ 
Table 1: Clinical Laboratory findings from hospital, (Day 1 to 14) (July 11-July 25, 2020)

\begin{tabular}{|c|c|c|c|c|}
\hline $\begin{array}{l}\text { Measurement } \\
\text { (Normal Reference range) }\end{array}$ & $\begin{array}{l}\text { Hospital } \\
\text { Day } 1\end{array}$ & $\begin{array}{l}\text { Hospital } \\
\text { Day } 4 \\
\end{array}$ & $\begin{array}{l}\text { Hospital } \\
\text { Day } 10\end{array}$ & $\begin{array}{c}\text { Hospital } \\
\text { Day } 14\end{array}$ \\
\hline Haemoglobin & $7.6 \mathrm{mg} / \mathrm{dL}$ & $7.5 \mathrm{mg} / \mathrm{dL}$ & $9.1 \mathrm{gm} / \mathrm{dL}$ & $6.2 \mathrm{gm} / \mathrm{dL}$ \\
\hline ESR $\left(0-15 \mathrm{~mm}\right.$ in $1^{\text {st }}$ hour $)$ & $74 \mathrm{~mm}$ in $2 \mathrm{st} \mathrm{hr}$ & $87 \mathrm{~mm}$ in $1^{\text {st }} \mathrm{hr}$ & $70 \mathrm{~mm}$ in $1^{\text {st }} \mathrm{hr}$ & $140 \mathrm{~mm}$ in $1^{\text {st }} \mathrm{hr}$ \\
\hline WBC (4000-11,000/cmm) & $14,000 / \mathrm{cmm}$ & $13,700 / \mathrm{cmm}$ & $17,000 / \mathrm{cmm}$ & $15,600 / \mathrm{cmm}$ \\
\hline $\begin{array}{l}\text { Neutrophils (Differentials) } \\
(40-75 \%)\end{array}$ & $70.0 \%$ & $79.0 \%$ & $89.0 \%$ & $85.0 \%$ \\
\hline Lymphocytes (Differential) & $13.0 \%$ & $14.0 \%$ & $18.0 \%$ & $6.0 \%$ \\
\hline Haematocrit (37-47\%) & $24.2 \%$ & $24.8 \%$ & & $20.0 \%$ \\
\hline $\begin{array}{l}\text { Platelet Count }(150,000- \\
400,00 / \mathrm{cmm})\end{array}$ & $172.000 / \mathrm{cmm}$ & $191,000 / \mathrm{cmm}$ & $112,000 / \mathrm{cmm}$ & $96,000 / \mathrm{cmm}$ \\
\hline Sodium $(135-145 \mathrm{nmol} / \mathrm{L})$ & $133.4 \mathrm{nmol} / \mathrm{L}$ & $138 \mathrm{nmol} / \mathrm{L}$ & $132 \mathrm{nmol} / \mathrm{L}$ & $133 \mathrm{nmol} / \mathrm{L}$ \\
\hline Potassium (3.5-5.0nmol/L) & $4.22 \mathrm{nmol} / \mathrm{L}$ & $4.5 \mathrm{nmol} / \mathrm{L}$ & $4.9 \mathrm{nmol} / \mathrm{L}$ & $5.8 \mathrm{nmol} / \mathrm{L}$ \\
\hline Chloride (98-107nmol/L) & $96.6 \mathrm{nmol} / \mathrm{L}$ & $101 \mathrm{nmol} / \mathrm{L})$ & $105 \mathrm{nmol} / \mathrm{L}$ & \\
\hline S. Calcium $(8.1-10.4 \mathrm{mg} / \mathrm{dl})$ & $6.1 \mathrm{mg} / \mathrm{dl}$ & & & \\
\hline S. creatinine $(0.5-1.2 \mathrm{mg} / \mathrm{dl})$ & $2.4 \mathrm{mg} / \mathrm{dl}$ & $2.7 \mathrm{mg} / \mathrm{dl}$ & $2.2 \mathrm{mg} / \mathrm{dl}$ & $3.4 \mathrm{mg} / \mathrm{dl}$ \\
\hline Phosphate $(2.5-5 \mathrm{mg} / \mathrm{dl})$ & $5.9 \mathrm{mg} / \mathrm{dl}$ & & & \\
\hline BUN $(6.0-21 \mathrm{mg} / \mathrm{dl})$ & $22.7 \mathrm{mg} / \mathrm{dl}$ & & & $39 \mathrm{mg} / \mathrm{dl}$ \\
\hline $\begin{array}{l}\text { Total Billirubin }(0.2-1.0 \\
\mathrm{mg} / \mathrm{dl})\end{array}$ & $1.2 \mathrm{mg} / \mathrm{dl}$ & $1.6 \mathrm{mg} / \mathrm{dl}$ & & $1.7 \mathrm{mg} / \mathrm{dl}$ \\
\hline S. Albumin $(3.8-5.1 \mathrm{~d} / \mathrm{dl})$ & $5.1 \mathrm{gm} / \mathrm{dl}$ & & $4.5 \mathrm{gm} / \mathrm{dl}$ & $4.6 \mathrm{gm} / \mathrm{dl}$ \\
\hline $\begin{array}{l}\text { Prothrombin time (Control } \\
13 . \mathrm{sec})\end{array}$ & $17.0 \mathrm{sec}$ & $14.0 \mathrm{sec}$ & $18.0 \mathrm{sec}$ & \\
\hline $\begin{array}{l}\text { Alanine aminotransferase } \\
\text { (Female up to } 32 \mathrm{U} / \mathrm{L} \text { ) }\end{array}$ & $54 \mathrm{U} / \mathrm{L}$ & & $102 \mathrm{U} / \mathrm{L}$ & 99U/L \\
\hline CRP (less than 6mg/L) & $48 \mathrm{mg} / \mathrm{l}$ & $51 \mathrm{mg} / \mathrm{l}$ & $75 \mathrm{mg} / \mathrm{ml}$ & $211 \mathrm{mg} / \mathrm{ml}$ \\
\hline D-dimer $(<0.5 \mathrm{mg} / \mathrm{ml})$ & $0.81 \mathrm{mg} / \mathrm{l}$ & $2.1 \mathrm{mg} / 1$ & $1.86 \mathrm{mg} / \mathrm{l}$ & $13.0 \mathrm{mg} / \mathrm{l}$ \\
\hline APTT (25-35) & & $\begin{array}{l}\text { Control:32 } \\
\text { Patient: } 27\end{array}$ & $\begin{array}{l}\text { Control:32 } \\
\text { Patient:28 }\end{array}$ & $\begin{array}{l}\text { Control:32 } \\
\text { Patient:33 }\end{array}$ \\
\hline Troponin I $(<0.1 \mathrm{ng} / \mathrm{ml})$ & $0.08 \mathrm{ng} / \mathrm{ml}$ & & $0.06 \mathrm{ng} / \mathrm{ml}$ & $<0.01 \mathrm{ng} / \mathrm{ml}$ \\
\hline $\begin{array}{l}\text { Serum Ferritin (Adult } \\
\text { Female } 15-120 \mathrm{ng} / \mathrm{ml})\end{array}$ & $711 \mathrm{ng} / \mathrm{ml}$ & $198 \mathrm{ng} / \mathrm{ml}$ & & $>1000 \mathrm{ng} / \mathrm{ml}$ \\
\hline $\begin{array}{l}\text { N terminal Pro BNP } \\
(<300 \mathrm{pg} / \mathrm{ml} \text { HF unlikely })\end{array}$ & $513 \mathrm{pg} / \mathrm{ml}$ & & $477 \mathrm{pg} / \mathrm{ml}$ & $910 \mathrm{pg} / \mathrm{ml}$ \\
\hline $\begin{array}{l}\text { Lactate dehydrogenase } \\
(200-400 \mathrm{U} / \mathrm{L})\end{array}$ & $410 \mathrm{U} / \mathrm{L}$ & & & $973 \mathrm{U} / \mathrm{L}$ \\
\hline $\begin{array}{l}24 \text { hour Urine Protein (Up } \\
\text { to } 0.15 \mathrm{gm} / 24 \mathrm{hrs})\end{array}$ & $0.54 \mathrm{gm} / 24 \mathrm{hrs}$ & & & \\
\hline S Procalcitonin $(<0.1 \mathrm{ng} / \mathrm{ml})$ & $<0.05 \mathrm{ng} / \mathrm{ml}$ & & & $2.7 \mathrm{ng} / \mathrm{ml}$ \\
\hline TSH $(0.3-5.05 \mu \mathrm{IU} / \mathrm{ml})$ & $1.93 \mu \mathrm{IU} / \mathrm{ml}$ & & & $2.08 \mu \mathrm{IU} / \mathrm{ml}$ \\
\hline Malarial Parasite & Not found & & & \\
\hline NS1 antigen for Dengue & Negative & & & \\
\hline Electrocardiogram(ECG) & $\begin{array}{l}\text { Anterior } \\
\text { ischaemia }\end{array}$ & & & $\begin{array}{c}\text { Atrial Fibrillation } \\
\text { with rapid } \\
\text { ventricular response }\end{array}$ \\
\hline $\begin{array}{l}\text { Seroimmunological Test for } \\
\text { Salmonella, Brucella and } \\
\text { Rickettsia }\end{array}$ & Not significant & & & \\
\hline Blood culture & No growth & & & \\
\hline
\end{tabular}




\section{Discussion}

COVID-19 appears to be associated with a strong thrombotic tendency due to thrombo-inflammation, probably driven by distinct mechanism that still require explanation ${ }^{8}$. In this case provides that how arterial thrombosis leads to very poor outcome in a patient with COVID-19 pneumonia. First, the case developed severe pneumonia starting antiviral and antibiotic for possible co-infection, thromboprophylaxis with high dose low molecular weight heparin, enoxaparin, subsequently developed arterial thrombosis of the right leg started promptly unfractionated heparin in continuous infusion. Presence of additional risk factor obesity, hypothyroidism, ischemic heart disease, hypertension, renal impairment also contributes to the condition and making it very difficult to manage. Further deterioration due to respiratory failure may be due to involvement of the pulmonary arterial thrombosis.

This case also shows the diagnostic challenges in patients with COVID-19 and in particular that deteriorate rapidly. We feel an impossible situation to differentiate between respiratory failure due to progression of severe pneumonia, acute respiratory distress syndrome in one side and pulmonary embolism in other side. In our case showed both, rapid progression of COVID-19 pneumonia, arterial thrombosis not responding to unfractionated heparin and probably consequent development of severe pulmonary embolism. Patient condition and facility does not make possible to confirm it by computed tomography pulmonary angiography (CTPA) in a severely ill patient.

One study suggest that the combination of D-dimer levels increasing progressively and clinical worsening is suggestive for pulmonary embolism ${ }^{12}$ and D-dimer elevations associated with poor prognosis which were similar to our case ${ }^{5}$. Acute limb ischemia is a limb threatening thromboembolic event that is considered as surgical emergency. A retrospective study suggests that patients who had undergone lower extremity revascularization procedures for acute limb ischemia revealed that $40.0 \%$ had some evidence of hypercoagulable state. An arterial thrombosis can easily retrieve with an open embolectomy procedure with prompt restoration of flow to the foot. In this case, revascularization cannot possible due to rapid deterioration of the patient. At last combined cascade make our dedicated team hopeless and to lose the patient on July 26, 2020.

\section{Conclusion}

This case emphasizes hypercoagulability as a major contributor to COVID-19 related complications and suggests that early diagnostic and therapeutic approaches as must implemented promptly to ameliorate the risk of thromboembolic events, prompt intervention to remove thrombus and control of co morbid condition. Further study should require for a clear recommendation for this dangerous complications related to COVID-19 to reduce morbidity and mortality. Interim rapid guideline also needed for the physicians to combat the situations.

Acknowledgement: To all the stuffs of Medinova Specialized Hospital for their tremendous support in the different stage of treatment of the patient

\section{References}

1. Coronavirus Update (Live): $39,261,100$ Cases and 1,104,185 Deaths from COVID-19 Virus Pandemic - Worldometer [Internet]. [cited 2020 Oct 16]. Available from: https://www.worldometers.info/coronavirus/

2. corona.gov.bd করোনা ভাইরাস ইনফো ২০১৯ |Coronavirus Disease 2019 (COVID-19) Information Bangladesh | corona.gov.bd [Internet]. [cited 2020 Oct 16]

3. Fabris F, Molaschi M, Aimonino N, Ponzetto M, Maero B, Tibaldi V, et al. Home Care for Demented Subjects: New Models of Care and Home-Care Allowance. Arch Gerontol Geriatr. 2004;38:155-62

4. Clinical Characteristics of 138 Hospitalized Patients with 2019 Novel Coronavirus-Infected Pneumonia in Wuhan, China Critical Care Medicine JAMA

5. Tang N, Bai H, Chen X, Gong J, Li D, Sun Z. Anticoagulant treatment is associated with decreased mortality in severe coronavirus disease 2019 patients with coagulopathy. J Thromb Haemost 2020;18(5):1094-9

6. Tang N, Li D, Wang X, Sun Z. Abnormal coagulation parameters are associated with poor prognosis in patients with novel coronavirus pneumonia. J Thromb Haemost 2020;18(4): $844-7$

7. Klok FA, Kruip MJHA, van der Meer NJM, Arbous MS, Gommers MPJ, Kant KM, et al. Incidence of thrombotic complications in critically ill ICU patients with COVID-19. Thromb Res. 2020;191:145-7

8. Cui S, Chen S, Li X, Liu S, Wang F. Prevalence of venous thromboembolism in patients with severe novel coronavirus pneumonia. J Thromb Haemost. 2020;18(6):1421-4.

9. Comorbidity and its Impact on Patients with COVID-19 [Internet]. [cited 2020 Oct 16]. Available from: https://www.ncbi.nlm.nih.gov/pmc/articles/PMC7314621/ 10. Garg S. Hospitalization Rates and Characteristics of Patients Hospitalized with Laboratory-Confirmed Coronavirus Disease 2019 MMWR Morb Mortal Wkly Rep 2020;69

11. Singh AK, Gupta R, Ghosh A, Misra A. Diabetes in COVID19: Prevalence, pathophysiology, prognosis and practical considerations. Diabetes Metab Syndr. 2020;14(4):303-10.

12. Oudkerk M, Büller HR, Kuijpers D, van Es N, Oudkerk SF, McLoud T, et al. Diagnosis, Prevention, and Treatment of Thromboembolic Complications in COVID-19: Report of the National Institute for Public Health of the Netherlands. Radiology. 2020;297(1):E216-22 